\title{
Evidence for avoidance of flushing from an estuary by a planktonic, phototrophic ciliate
}

\author{
David W. Crawford*, Duncan A. Purdie \\ Department of Oceanography, The University, Highfield, Southampton, SO9 5NH, UK
}

\begin{abstract}
The vertical distribution of the planktonic, phototrophic ciliate Mesodinium rubrum was monitored during a red-water event in daylight hours, over a complete tidal cycle. Theoretical considerations based upon the hydrodynamics of the estuary, and upon the behaviour of the ciliate described to date, suggest that the population should not be able to resist flushing losses from the estuary. However, field observations reveal a pattern consisting of aggregation close to the surface during flood tide and high water, but dispersion away from the surface on the ebb tide, thus minimizing flushing losses due to the strong superficial currents. Evidence is presented suggesting that the major cue for such migration may be the turbulence generated by shearing of surface currents, or gravitational (static) instability of surface water.
\end{abstract}

\section{INTRODUCTION}

Tidal flushing is accepted to be a fundamental factor controlling the development of plankton populations in estuaries (Ketchum 1954). Several bloom-forming dinoflagellate species reduce flushing losses indirectly, through surface avoidance, by combinations of motile responses to various abiotic parameters, such as light, temperature, salinity and nutrients (e.g. Eppley et al. 1968, Anderson \& Stolzenbach 1985, Chang \& Carpenter 1985). Although the role of ciliates in marine ecosystems has also attracted much recent interest as an important component of the microplankton (e.g. Beers et al. 1980, Smetacek 1981), the adaptive significance of their considerably greater motile capacity has received only limited attention to date (e.g. Dale 1987, Jonsson 1989). Moreover, recent observations on the abundance of mixotrophic and phototrophic ciliates (Stoecker et al. 1987, 1989, Crawford 1989) suggest that significant quantities of planktonic chlorophyll may be packaged in forms with much greater mobility than previously anticipated.

The planktonic ciliate Mesodinium rubrum (Lohmann) Hamburger \& Buddenbrock forms non-toxic

\footnotetext{
•Present address: University Marine Biological Station, Millport, Isle of Cumbrae, Scotland, KA28 0EG, UK
}

red-water blooms around the world in coastal and upwelling ecosystems (Taylor et al. 1971, Lindholm 1985). M. rubrum is enabled to be an obligate, functional phototroph (Ryther 1967, Barber et al. 1969) by the presence of an algal (cryptomonad) endosymbiont (Hibberd 1977). It is thought to be the most strongly integrated association known between host and photosynthetic cytobiont (Taylor 1982), and has been responsible for some of the highest rates of planktonic primary productivity on record (Taylor 1982, Lindholm 1985). Thus, often erroneously grouped within the microzooplankton, $M$. rubrum is functionally a member of the phytoplankton (Sieburth et al. 1978, Lindholm 1985, Crawford 1989), and has been seriously neglected as such in routine surveys to date (Crawford 1989). M. rubrum attains phenomenal swimming speeds of over $8 \mathrm{~mm} \mathrm{~s}^{-1}$ (ca 200 body lengths $\mathrm{s}^{-1}$; Lindholm 1985, Jonsson \& Tiselius 1990), an order of magnitude greater than the majority of dinoflagellates (Smith \& Barber 1979) and several times quicker than most ciliates (Sleigh \& Blake 1977. Dale 1987). Such swimming speed enables $M$. rubrum to perform diurnal vertical migrations of some $40 \mathrm{~m}$ in the Peru upwelling zone (Smith \& Barber 1979).

Mesodinium rubrum causes recurrent red-water events each summer and autumn in Southampton Water, England (Williams 1980, Soulsby et al. 1984), an estuary characterised by a peculiar tidal regime 
consisting of a double high water, some $2 \mathrm{~h}$ apart, followed by a short ebb tide with near-surface currents reaching 0.5 to $1.0 \mathrm{~m} \mathrm{~s}^{-1}$ (Dyer 1973). M. rubrum is usually described as forming discrete surface or subsurface ( 1 to $2 \mathrm{~m}$ ) maxima during the day, apparently in response to light (Bary \& Stuckey 1950, Smith \& Barber 1979), and swimming down or dispersing at night (Smith \& Barber 1979, Soulsby et al. 1984). However, this behaviour pattern would clearly place the bulk of the population in a zone of intense nearsurface currents during daytime ebb tides. Here, we examine evidence for a mechanism by which $M$. rubrum could maintain itself in the estuary when faced with such potential flushing losses.

\section{MATERIALS AND METHODS}

Surveys were conducted during the summers of 1985 and 1986 from a small research launch, anchored at Eling buoy, at the head of the River Test/Southampton Water estuary (Fig. 1). In such a dynamic estuary, it is impossible to track a body of water over the tidal cycle, using a drifting boat for example; the strong surface currents carry the boat swiftly downstream on the ebb tide, giving no advantage over the anchored boat.

In July 1985, sampling was undertaken over a complete tidal cycle. Water samples were taken with a Van-Dorn bottle at 4 depths $(1,4,7$, and $10 \mathrm{~m})$, staggered at 15 min intervals, each depth sampled once every hour. Subsamples of $125 \mathrm{ml}$ were preserved with $1 \%$ Lugol's iodine (see Crawford 1989) immediately after sampling, and stored in amber glass bottles in the dark for subsequent cell counts. Mesodinium rubrum was enumerated (after concentration by sedimentation, when necessary) in a Sedgewick-Rafter counting chamber, using an Olympus BH2 microscope. Vertical profiles of physical parameters were taken at $1 \mathrm{~m}$ intervals every 20 min using a NBA CTU- 1 profiling CTD and NBA current meter.

In July 1986, Mesodinium rubrum distribution was monitored over ca $8 \mathrm{~h}$, using in situ chlorophyll fluorescence as an index of abundance; approximately every $2 \mathrm{~h}$ at $1 \mathrm{~m}$ intervals, water samples were pumped through a Turner Designs flow-through fluorometer. Only changes in relative fluorescence are shown; peaks represent chlorophyll levels in excess of $100 \mathrm{mg}$ $\mathrm{m}^{-3}$ and were dominated by $M$. rubrum $\left(100 \mathrm{mg} \mathrm{m}^{-3}\right.$ chlorophyll a represents approximately $10^{9}$ cells $\mathrm{m}^{-3}$ ).

\section{RESULTS}

Tidal advection past the fixed anchor station revealed significant horizontal fluctuations in the abundance of Mesodinium rubrum. To account for this, vertical distribution of $M$. rubrum (Figs. 2 \& 3) was represented as percentages of the total numbers integrated from the surface to $10 \mathrm{~m}$; cell numbers $\left(\mathrm{m}^{-3}\right)$ were first expressed, at any given $1 \mathrm{~m}$ depth interval as a percentage of the total integrated population (cells $\mathrm{m}^{-2}$ ). The depth, from the surface, of the $50 \%$ 'centre of gravity' of the population (thick solid line) was then derived, together with the 20 and $80 \%$ levels (stippled area between upper and lower dashed lines) to show degree of aggregation. This representation of population distribution is likely to considerably underestimate the actual degree of aggregation, since only 4 depths were sampled; this species aggregates to such an extent that a sampling interval of 0.5 to $1 \mathrm{~m}$ is preferable (Crawford 1989, Lindholm \& Mörk 1990), though not always logistically feasible.

Fig. 2 shows the relationship, over a tidal cycle, between vertical distribution of Mesodinium rubrum

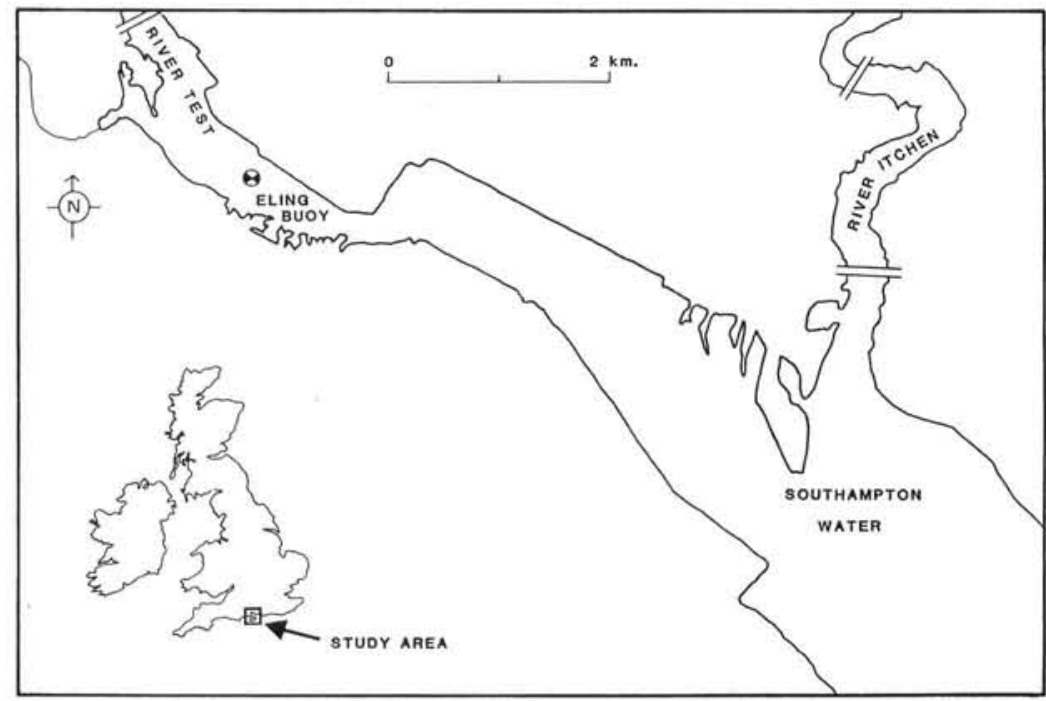

Fig. 1. Location of Eling buoy fixed anchor station at head of Test River/Southampton Water estuary 

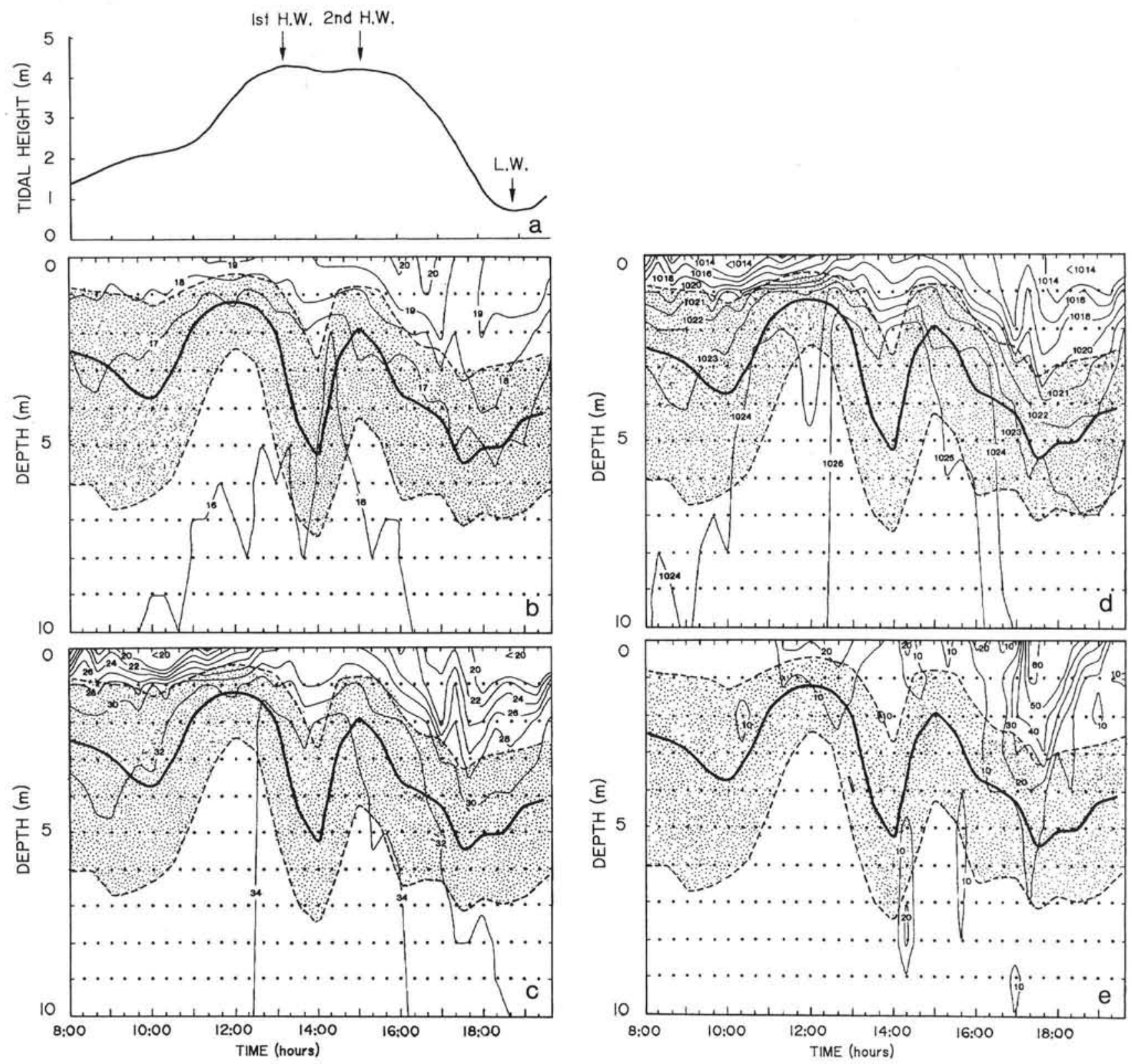

Fig. 2. Relationship between vertical distribution of Mesodinium rubrum and contours of physical parameters of the water column over a tidal cycle during a red-water event at Eling buoy in July 1985. Fine line contours represent: (a) tidal height, m; (b) temperature, ${ }^{\circ} \mathrm{C}$; (c) salinity, \%o; (d) density, $\mathrm{g} \mathrm{l}^{-1}$; (e) current speed, $\mathrm{cm} \mathrm{s}^{-1}$. Data points represent frequency of physical measurements. The thick solid line represents the depth, from the surface, of the $50 \%$ 'centre of gravity' of the integrated population of M. rubrum; the degree of aggegation is indicated by the stippled area between upper and lower dashed lines, representing the $20 \%$ and $80 \%$ levels respectively (see text for further explanation)

(as described above) and physical properties of the water column. Use of contours allows visual separation of migrational and advective phenomena, i.e. whether population contours followed those of water mass properties. It was evident that during the ebb tide, between 15:00 and 18:00 $\mathrm{h}$, the population deepened considerably, and thus was not exposed to the near-surface flow, where flushing is greatest. Some coherence was apparent between the population maximum and the physical parameters during the ebb tide. The relationship with the $17^{\circ} \mathrm{C}$ isotherm appeared strongest and could represent either a migration, with temperature as a cue, or an artifact resulting from advective changes, with the population residing at a preferential optimum temperature. However, neither interpretation is supported by the sharp but temporary downward displacement without apparent cue, which occurred approximately be- 


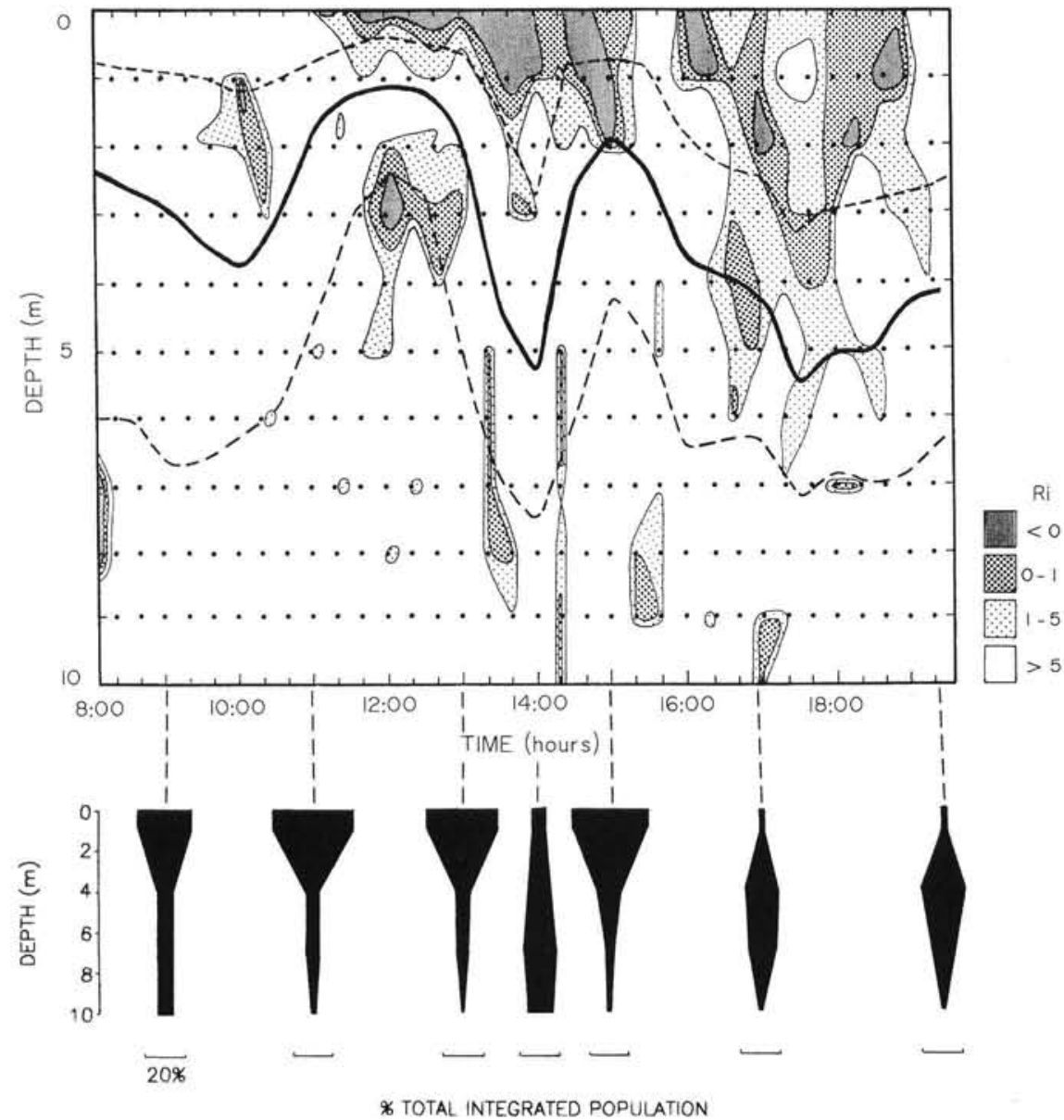

Fig. 3. Relationship between vertical distribution of Mesodinium rubrum (as indicated in Fig. 2) and dynamic stability of the water column, represented by the Richardson Number (see text for definition). The black shaded 'silhouettes' below emphasize more graphically the vertical distribution of $M$. rubrum at certain points during the tidal cycle; vertical distribution is represented as percentage of total integrated population tween 1st and 2nd high waters (12:00 to 14:00 h). During this period, the population maximum crossed contours of temperature, salinity and density, while current speed remained relatively stable. Salinity, and density in particular, showed evidence of a mixing event, although the slope of contours of population displacement was much sharper than those of either factor.

To further investigate the role of mixing, density and current speed profiles were transformed into an index of dynamic stability, represented by the Richardson Number (Ri), as shown in the contour plot in Fig. 3:

$$
R i=\frac{-g / \rho(\delta \rho / \delta z)}{(\delta u / \delta z)^{2}}
$$

(Dyer 1973)

where $g=$ gravitational constant; $\rho=$ density; $u=$ current velocity; $z=$ depth. $R i$ is a dimensionless index of the stabilizing effect of buoyancy, generated by the density profile, against the destabilizing effect of vertical current shear. The critical threshold value below which shear forces generate turbulence is $R i=$ 0.25 (Dyer 1973), though in estuaries this is accepted to be closer to $R i=1$. Below $R i=0$, turbulence results from static instability.
The period between the 2 high waters was characterised by surface turbulence extending down to $3 \mathrm{~m}$, principally generated by gravitational instability (Fig. 3). The population maximum appeared either to avoid or be mixed downward by this increased turbulence. The coherence between the slope of $\mathrm{Ri}$ contours with those of the population distribution is remarkable. Since the bulk of the population remained within a zone of 'stable' water $(R i>1)$, and depth regulation is possible even by weakly motile phytoplankton when $R i=0.5$ to 1.0 (Ganf 1974), this would suggest that the majority of Mesodinium rubrum cells were not subject to vertical mixing, but rather may have been actively aggregating away from surface turbulence. At about 12:00 h, the population even appeared to be 'squeezed' between turbulence close to the surface and a turbulence zone (probably shear-generated) at about 2 to $3 \mathrm{~m}$. Over the tidal cycle as a whole, the population maximum tended away from turbulent mixing zones, except briefly during ebb tide, where contours of $R i<1$ were crossed. On the ebb tide, turbulence is principally generated by the shearing of surface currents. 


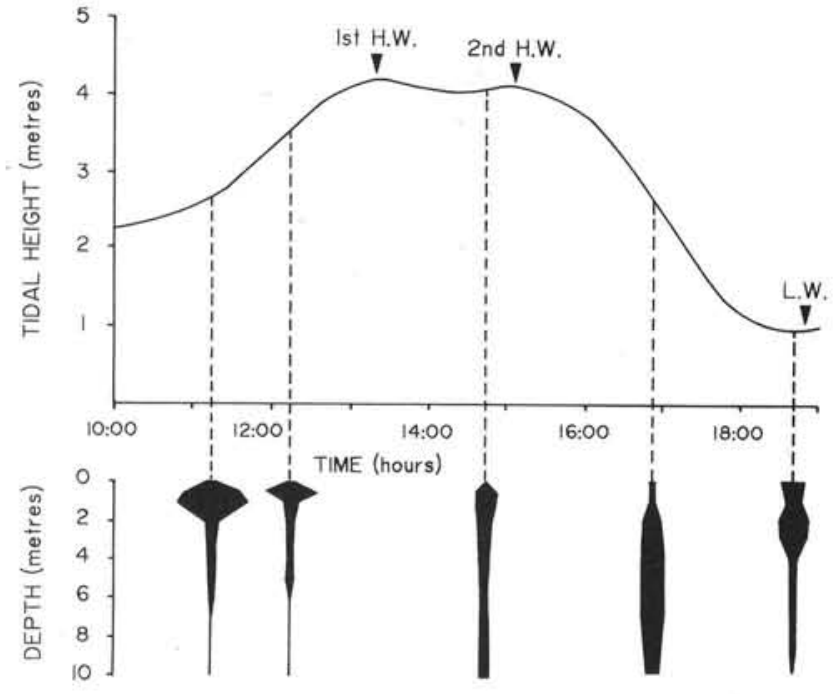

RELATIVE FLUORESCENCE (arbitrary units)

Fig. 4. Vertical profiles of chlorophyll fluorescence (relative units) over a portion of the tidal cycle taken at Eling buoy during a red-tide caused by Mesodinium rubrum in July 1986. Fluorescence is adopted as an indicator of abundance of M. rubrum, which dominated the phytoplankton

Fig. 4 shows vertical profiles of Mesodinium rubrum from the field survey undertaken to confirm the observed changes described above. Again a similar pattern emerged, with aggregation closer to the surface on the flood tide, and a deeper, more dispersed population on the ebb tide. A dispersed population was again apparent between the 2 high waters, but unfortunately a profile was not taken to confirm whether re-aggregation occurred on the 2 nd high water. Although a small proportion of the population appeared to remain at the surface during ebb tide, it should be noted that Fig. 4 represents in situ fluorescence, thus other species may be represented. However, Figs. 2 \& 3 also show some cells of $M$. rubrum at the surface during ebb tide; if our observations do indeed represent a response to turbulence, then a few cells at the surface would be expected, since avoidance could be upward away from subsurface shearing currents, thus 'trapping' some cells close to the surface.

\section{DISCUSSION}

Our data clearly show that the population maximum of Mesodinium rubrum in Southampton Water, at least during red tides, is deeper and more dispersed on the ebb than on the flood tide or during slack water. In terms of estuary dynamics, and perhaps in retrospect, such a finding was almost inevitable; a behaviour pattern governed simply by phototactic aggregation close to the surface, as previously suggested (see Lindholm 1985 for review), would result in the advection by near-surface currents of the bulk of the population at least $5 \mathrm{~km}$ downstream on each daytime ebb tide. In contrast, the red-water typically maintains itself most intensely at the head of the estuary for several weeks without evidence of extensive flushing losses; the mouth of the estuary is characterised by very low numbers of $M$. rubrum. The observations are further supported by data obtained during a survey of the estuary using the airborne thematic mapper to determine the spatial distribution of the bloom (Purdie \& Garcia 1988); surface chlorophyll throughout the upper estuary was shown to be significantly reduced on the ebb tide, suggesting a downward migration (C. A. E. Garcia pers. comm.).

The implications of these observations are critical to the development and retention of red tides within the estuary; the ability of Mesodinium rubrum to concentrate close to the surface under optimal light conditions, but then avoid flushing losses on the ebb tide, is a crucial advantage over other members of the phytoplankton. M. rubrum has also been similarly shown to utilise a diurnal vertical migration of $40 \mathrm{~m}$ (Smith \& Barber 1979) in a 2-layered flow to negate offshore displacement and thus maintain and concentrate the population in the Peru upwelling system (Barber \& Smith 1981).

The mechanism by which Mesodinium rubrum could avoid surface flushing is less clear but particularly interesting. Although it cannot be firmly established from this field study that such changes in vertical distribution directly resulted from active avoidance of turbulence, the evidence presented is suggestive. Although the abundance maximum showed some coherence with temperature, salinity and density over a portion of the tidal cycle, only contours of Richardson Numbers $(R i)$ provided an explanation for the vertical displacements throughout tidal cycle. Surface incident light intensity was not determined; however, the survey was undertaken on a cloudless sunny day with insufficient variation in light intensity to result in vertical migration of several meters at midday. The return of the population toward the surface in decreasing light, in the evening after the ebb tide (Figs. 2 to 4 ), also suggests that light was not a major factor during daylight hours. However, this does not necessarily argue for light-independence for the vertical migration of M. rubrum; on the contrary, it appears to be strongly phototactic (see Lindholm 1985 for review) and has been reported to exhibit a diurnal migration pattern in Southampton Water (Soulsby et al. 1984) with nearsurface accumulation during the day, and downward dispersal during darkness. Such a pattern would, to some extent, reduce flushing losses in itself when ebb 
tide occurs during dark hours. Our study provides considerably greater temporal resolution than acheived previously however, and we suggest that an active response to turbulence could be superimposed upon the diurnal pattern i.e. when positive phototaxis draws the population into unstable near-surface waters.

We acknowledge the limitations of our study due to the lack of repeated surveys when tidal and diurnal cycles are in a different phase, i.e. when ebb tide occurs during darkness or early morning. Thus, the afternoon descent of Mesodinium rubrum described here could simply represent a phenomenon typical of many migrating dinoflagellates. Nevertheless, the sharp downward displacement between 12:00 and 14:00 h (Figs. $2 \&$ 3), apparently with only turbulence as a cue, and the return of the population toward the surface after ebb tide (Figs. 2 to 4 ) support our contentions. We cannot discount the possibility that the observed distributions may represent the resultant pattern of a combination of interacting factors; however, we feel that the relationship with turbulence is of sufficient novel interest to merit attention.

Experimental verification of turbulence avoidance has not been feasible at this stage; Mesodinium rubrum has not yet been cultured, is extremely fragile, and does not respond well to laboratory containment (Lindholm 1985). However, the interpretation of aggregation away from turbulence is supported by other published evidence. By means of rapid swimming, in response to small scale water movements, $M$. rubrum avoids isolation by micropipette (Taylor et al. 1971, Lindholm 1985, Crawford unpubl.) and substantially reduces capture efficiency by the feeding appendages of the copepod Acartia tonsa (Jonsson \& Tiselius 1990). Since the motile behaviour of $M$. rubrum alternates between rapid 'jumps' and periods of motionlessness (Lindholm 1985, Crawford 1989, Jonsson \& Tiselius 1990), an increase in the frequency of 'jumps' in response to turbulence would result in a net aggregation in more stable zones of the water column (i.e. a directional response is not required). The apparent upward 'squeezing' of the population by turbulence from below at 12:00 h supports this contention. Such increased 'escape' responses under turbulent conditions has recently been documented for the marine copepod Centropages hamatus (Costello et al. 1990). The mechanism by which so small an organism as M. rubrum (15 to $70 \mu \mathrm{m}$ cell diameter) could sense fluid deformations is more difficult to resolve. Detection of microscale shear currents must be suspected, though this would be on a scale $(<100 \mu \mathrm{m})$ poorly understood by hydrodynamicists. The smallest turbulent length scale shown to stimulate dinoflagellate bioluminescence is on the order of $33 \mu \mathrm{m}$ (Rohr et al. 1990), thus small scale shear could feasibly act as a cue. Sensing of acceleration forces using statocyst-like bodies, as described in the ciliate Loxodes sp. (Fenchel \& Finlay 1986), is also conceivable, though no such structures have been described in ultrastructural studies on M. rubrum to date. Jonsson (1989) presented a hypothesis for the surface accumulation of oligotrichs and tintinnids based upon net upward swimming or passive geotaxis, which depended on the asymmetry of cell morphology. This seems unlikely to be a major factor explaining migration in $M$. rubrum, which is both a more symmetrical cell (equatorial band of cilia and cirri) and capable of much more extended diurnal migrations than other species (see Lindholm 1985).

The role of turbulence in red tide ecology has clearly been underestimated, and is only now becoming fully apparent. Turbulence has been shown to interfere with growth (White 1976), cell division (Pollinger \& Zemel 1981) and motility (Thomas \& Gibson 1990a, b) in some dinoflagellates. Further research is imperative, since turbulence is not a routinely quantified parameter in plankton studies. Other studies have already documented the retention of dinoflagellates in estuaries through surface avoidance; however, the mechanisms appear to have been different, although turbulence was not measured. Anderson \& Stolzenbach (1985) suggested that Alexandrium (Gonyaulax) tamarensis and Heterocapsa triquetra reduced flushing losses by means of avoidance of high surface light intensities. Using a dye-injection technique in a small estuarine embayment, Garcon et al. (1986) demonstrated that A. tamarensis, whose growth rate approximated the rate of tidal flushing, could only bloom by such avoidance of outflowing surface waters.

More generally, the implications of our observations may be far-reaching. Our study is quite atypical in providing an opportunity to simultaneously examine the vertical distribution of a motile microplankter, together with the physical properties defining water column stability on a scale relevant to the organism. Intuitive or empirical estimates of static stability are often derived from density gradients during plankton studies, but velocity profiles, allowing direct assessment of dynamic stability, are rarely measured (Heaney \& Butterwick 1985). Mechanoreceptorinduced escape reactions are a widespread phenomenon among the macro- and microplankton; however, the potential combined role of turbulence with such responses as a factor influencing microscale patchiness surely merits further investigation.

Acknowledgements. This work was funded by N.E.R.C. grant no. GR3/5683. Drs N. Taylor and S. Boxall kindly provided the raw physical data. We thank Kate Saull and Rachel Scott for assistance with the figures. We are particularly grateful for the constructive comments of 2 anonymous reviewers. 


\section{LITERATURE CITED}

Anderson, D. M., Stolzenbach, K. D. (1985). Selective retention of two dinoflagellates in a well-mixed coastal embayment: the importance of diel vertical migration and surface avoidance. Mar. Ecol. Prog. Ser. 25: 39-50

Barber, R. T., Smith, W. O. (1981). The role of circulation, sinking and vertical migration in physical sorting of phytoplankton in the upwelling centre at $15 \mathrm{~N}$. In: Richards, F. A. (ed.) Coastal upwelling: coastal and estuarine sciences 1. Geophysical Monography Bd, Washington, D.C., p. $366-371$

Barber, R. T., White, A. W., Siegelman, H. W. (1969). Evidence for a cryptomonad symbiont in the ciliate Cyclotrichium meunieri. J. Phycol. 5: 86-88

Bary, B. M., Stuckey, R. G. (1950). An occurrence in Wellington Harbour of Cyclotrichium meunieri Powers, a ciliate causing red water, with some additions to its morphology. Trans. R. Soc. N. Z. 78: 86-92

Beers, J. R., Reid, F. M. H., Stewart, G. L. (1980). Microplankton population structure in southern California nearshore waters in late spring. Mar. Biol. 60: 209-226

Chang, J., Carpenter, E. J. (1985). Blooms of the dinoflagellate Gyrodinium aureolum in a Long Island estuary: box model analysis of bloom maintenance. Mar. Biol. 89: 83-93

Costello, J. H., Strickler, J. R., Marrasé, C., Trager, G., Zeller, R., Freise, A. J. (1990). Grazing in a turbulent environment: behavioural response of a calanoid copepod, Centropages hamatus. Proc. natn. Acad. Sci. U.S.A. 87; 1648-1652

Crawford, D. W. (1989). Mesodinium rubrum: the phytoplankter that wasn't. Mar. Ecol. Prog. Ser. 58: 161-174

Dale, T. (1987). Diel vertical distribution of planktonic ciliates in Lindåspollene, western Norway. Mar. microb. Fd Webs 2: $15-28$

Dyer, K. (1973). Estuaries: a physical introduction. John Wiley \& Sons, London

Eppley, R. W., Holm-Hansen, O., Strickland, J. D. H. (1968), Some observations on the vertical migration of dinoflagellates. J. Phycol. 4: 333-340

Fenchel, T., Finlay, B. J. (1986). The structure and function of Muller vesicles in loxodid ciliates. J. Protozool. 33: 69-79

Ganf, G. G. (1974). Diurnal mixing and the vertical distribution of phytoplankton in a shallow equatorial lake (Lake George, Uganda). J. Ecol. 62: 611-629

Garcon, V. C., Stolzenbach, K. D., Anderson, D. M. (1986). Tidal flushing of an estuarine embayment subject to recurrent dinoflagellate blooms. Estuaries 9: 179-187

Heaney, S. I., Butterwick, C. (1985). Comparative mechanisms of algal movement in relation to phytoplankton production. Contrib. mar. Sci. 27 (Suppl.): 114-134

Hibberd, D. J. (1977). Ultrastructure of the cryptomonad endosymbiont of the red-water ciliate Mesodinium rubrum. J. mar. biol. Ass. U.K. 57: 45-61

Jonsson, P. R. (1989). Vertical distribution of planktonic ciliates - an experimental analysis of swimming behaviour. Mar. Ecol. Prog. Ser. 52: 39-53

Jonsson, P. R., Tiselius, P. (1990). Feeding behaviour, prey detection and capture efficiency of the copepod Acartia tonsa feeding on planktonic ciliates. Mar. Ecol. Prog. Ser. 60: $35-44$

This article was presented by D. K. Stoecker, Cambridge, Maryland, USA
Ketchum, B. H. (1954). Relation between circulation and planktonic populations in estuaries. Ecology 35: 191-200

Lindholm, T. (1985). Mesodinium rubrum - a unique photosynthetic ciliate, Adv, aquat. Microbiol. 3: 1-48

Lindholm, T., Mörk, A. C. (1990). Depth maxima of Mesodinium rubrum (Lohmann) Hamburger \& Buddenbrock examples from a stratified Baltic Sea inlet. Sarsia 75: 53-64

Pollingher, U., Zemel, E. (1981). In-situ and experimental evidence of the influence of turbulence on cell division processes of Peridinium cinctum forma westii (Lemm.) Lefevre. Br. phycol. J. 16: 281-287

Purdie, D. A., Garcia, C. A. E. (1988), The use of airborne thematic mapper data in studying the effect of tidal state on the distribution of phytoplankton blooms in Southampton Water. In: Proc. NERC 1987 Airborne Campaign Workshop, Univ. Southampton, U.K., p. 195-203

Rohr, J., Losee, J., Hoyt, J. (1990). Stimulation of bioluminescence by turbulent pipe flow. Deep Sea Res. 37: $1639-1646$

Ryther, J. H. (1967). Occurrence of red-water off Peru. Nature, Lond. 214: 1318-1319

Sieburth, J. McN., Smetacek, V., Lenz, F. (1987). Pelagic ecosystem structure: heterotrophic compartments of the plankton and their relationship to plankton size fractions. Limnol. Oceanogr. 23: 1256-1263

Sleigh, M., Blake, J. R. (1977). Methods of ciliary propulsion and their size limitations. In: Pedley, T. J. (ed.) Scale effects in animal locomotion. Academic Press, London, p. 243-256

Smetacek, V. (1981). The annual cycle of protozooplankton in the Kiel Bight. Mar. Biol. 63: 1-11

Smith, W. O., Barber, R. T. (1979). A carbon budget for the autotrophic ciliate Mesodinium rubrum. J. Phycol, 15: $27-33$

Soulsby, P. G., Mollowney, M., Marsh, G., Lowthion, D. (1984). The role of phytoplankton in the dissolved oxygen budget of a stratified estuary. Wat. Sci. Tech. 17: 745-756

Stoecker, D. K., Michaels, A. E., Davis, L. H. (1987). Large proportion of planktonic ciliates found to contain functional chloroplasts. Nature, Lond. 326: 790-792

Stoecker, D. K., Taniguchi, A., Michaels, A. E. (1989). Abundance of autotrophic, mixotrophic, and heterotrophic planktonic ciliates in shelf and slope waters. Mar. Ecol. Prog. Ser. 50: 241-254

Taylor, F. J. R. (1982). Symbioses in marine microplankton. Annls Inst. océanogr. Paris, Fasc. Suppl. 58: 61-90

Taylor, F. J. R., Blackbourn, D. J., Blackbourn, J. (1971). The red-water ciliate Mesodinium rubrum and its incomplete symbionts: a review including new ultrastructural observations. J. Fish. Res. Bd Can. 28: 391-407

Thomas, W. H., Gibson, C. H. (1990a). Quantified small-scale turbulence inhibits a red tide dinoflagellate, Gonyaulax polyedra Stein. Deep Sea Res. 37: 1583-1593

Thomas, W. H., Gibson, C. H. (1990b). Effects of small-scale turbulence on microalgae. J. appl. Phycol. 2: 71-77

White, A. W. (1976). Growth inhibition caused by turbulence in the toxic marine dinoflagellate Gonyaulax excavata. J. Fish. Res. Bd Can. 33: 2598-2602

Williams, P. J. leB, (1980). Phytoplankton in Southampton Water. In: The Solent estuarine system. NERC Publications, Series C, 22: 73-75

Manuscript first received: April 11, 1991

Revised version accepted: December 10, 1991 